\title{
Pembelajaran kooperatif tipe CORE (connecting - organizing - reflecting - extending) terhadap kemampuan komunikasi matematis siswa pada siswa kelas VIII SMP
}

\section{Nina Niarti ${ }^{*}$, Syahrul Azmi², Muhammad Turmuzi², Laila Hayati ${ }^{2}$}

\author{
${ }^{1}$ Mahasiswa Pendidikan Matematika, FKIP, Universitas Mataram, Mataram \\ 2 Pendidikan Matematika, FKIP, Universitas Mataram, Mataram \\ ninaniarti01@gmail.com
}

Diterima: 16-09-2021; Direvisi: 26-09-2021; Dipublikasi: 30-09-2021

\begin{abstract}
This study aims to determine the influence of the cooperative learning model CORE type on the mathematical communication skills at the eight grade students of SMPN 2 Kediri in Academic Year $2019 / 2020$ on cube and block material. The method used in this study was a quasi-experimental research design with post-test only control group design. The population of this study were all eight grade students of SMPN 2 Kediri in academic year 2019/2020, which were distributed in three classes. The sample class was selected using cluster random sampling technique, obtained class VIII-B as the experimental class and class VIII-C as the control class. As for data collection techniques, namely observation and tests. The data analysis technique used the prerequisite test, namely the normality test and the homogeneity test followed by the pooled variance t-test. Based on the results of data analysis, it was found that there was a difference between the mathematical communication skills of students who obtained the cooperative learning model CORE type and those who used the direct learning model. Classes that using the CORE model get an average score of 77.86 while those taught with the direct learning model get an average score of 65.15. This shows that learning using the cooperative model type CORE has an influence on the mathematical communication skills of students of class VIII SMPN 2 Kediri in academic year.
\end{abstract}

Keywords: cooperative learning model type core; mathematical communication skills; cubes and blocks

\begin{abstract}
Abstrak
Penelitian ini bertujuan untuk mengetahui pengaruh model pembelajaran CORE terhadap kemampuan komunikasi matematis siswa kelas VIII SMPN 2 Kediri Tahun Ajaran 2019/2020 pada materi kubus dan balok. Metode yang digunakan dalam penelitian ini adalah eksperimen semu dengan desain penelitian post-test only control group design. Populasi penelitian ini adalah seluruh siswa kelas VIII SMP Negeri 2 Kediri Tahun Ajaran 2019/2020 yang terdistribusi dalam tiga kelas. Kelas sampel dipilih menggunakan teknik cluster random sampling, diperoleh kelas VIII-B sebagai kelas eksperimen dan kelas VIII-C sebagai kelas kontrol. Adapun untuk teknik pengumpulan data yaitu observasi dan tes. Teknik analisis data menggunakan uji prasyarat yaitu uji normalitas dan uji homogenitas dan dilanjutkan dengan uji-t pooled varians. Berdasarkan hasil analisis data ditemukan bahwa terdapat perbedaan antara kemampuan komunikasi matematis siswa yang memperoleh model pembelajaran kooperatif tipe CORE dengan yang menggunakan model pembelajaran lengsung. Kelas yang menerapkan model CORE mendapatkan nilai rata-rata sebesar 77,86 sedangkan yang menerapkan model pembelajaran langsung memperoleh nilai ratarata 65,15 . Hal ini menunjukkan bahwa pembelajaran yang menggunakan model kooperatif tipe CORE memberikan pengaruh terhadap kemampuan komunikasi matematis siswa kelas VIII SMPN 2 Kediri.
\end{abstract}

Kata Kunci: model pembelajaran kooperatif tipe core; kemampuan komunikasi matematis; kubus dan balok. 


\section{PENDAHULUAN}

Kemampuan komunikasi matematis perlu dikembangkan. Baroody dalam (Ansari, 2016) menyatakan bahwa sedikitnya ada dua alasan penting mengapa komunikasi dalam pembelajaran matematika perlu ditumbuh kembangkan di sekolah. Pertama, matematika tidak hanya sekedar alat bantu berpikir, alat untuk menemukan pola, menyelesaikan masalah atau mengambil keputusan tetapi matematika juga sebagai alat untuk mengkomunikasikan berbagai ide dengan jelas, tepat dan ringkas. Kedua, sebagai aktivitas sosial dalam pembelajaran matematika di sekolah, matematika juga sebagai wahana interaksi antar siswa dan juga sebagai sarana komunikasi guru dan siswa. Kemampuan komunikasi matematis siswa dapat dikembangkan melalui proses pembelajaran di sekolah, salah satunya adalah proses pembelajaran matematika. Dengan demikian, matematika memiliki peran penting terhadap perkembangan kemampuan komunikasi matematisnya.

Kemampuan komunikasi matematis adalah kemampuan siswa dalam menyampaikan ide-ide matematika baik secara lisan maupun tulisan. Komunikasi lisan dapat diartikan sebagai suatu peristiwa saling interaksi (dialog) yang terjadi dalam suatu lingkungan kelas atau kelompok kecil, dan terjadi pengalihan pesan berisi tentang materi matematika yang sedang dipelajari baik antar guru dengan siswa maupun antar siswa itu sendiri. Sedangkan komunikasi tulisan adalah kemampuan atau keterampilan siswa dalam mengungkapkan ide matematika melalui gambar/grafik, tebel, persamaan, ataupun dengan bahasa siswa sendiri (Hodiyanto, 2018).

Berdasarkan hasil observasi di SMP Negeri 2 Kediri pada tanggal 16-18 Mei 2019, diperoleh bahwa pada saat kegiatan pembelajaran guru masih menggunakan pembelajaran langsung, yaitu pembelajaran yang lebih banyak didominasi oleh guru sebagai pemberi ilmu, sementara siswa lebih pasif sebagai penerima ilmu. Hasil pengamatan di kelas siswa belum berperan aktif dalam mengonstruksi pengetahuannya sendiri. Hal ini terlihat saat guru selesai menerangkan, tidak ada siswa yang bertanya mengenai materi tersebut, sehingga siswa kurang dapat mengungkapkan ide yang mereka punya, termasuk pada saat mengkoneksikan pengetahuan baru siswa dengan materi yang telah dipelajari sebelumnya. Misalnya seperti saat belajar tentang bangun ruang masih banyak siswa yang belum memahami materi bangun datar.

Adapun hasil wawancara dengan salah satu guru matematika yang mengajar di SMP Negeri 2 Kediri diperoleh informasi bahwa terdapat beberapa kesulitan yang dialami siswa dalam belajar matematika. Kesulitan yang dimaksud yaitu 1) siswa kesulitan dalam menjelaskan dan menghubungkan permasalahan sehari-hari ke dalam kalimat matematika, 2) kurangnnya ketepatan siswa dalam menyebutkan simbol atau notasi matematika, 3) siswa tidak terbiasa menuliskan apa yang diketahui dan apa yang ditanyakan dalam menyelesaikan soal, dan 4) siswa kesulitan dalam membuat kesimpulan. Menurut Sumarmo dalam (Asnawati, 2017) kesulitan-kesulitan yang dialami siswa merupakan beberapa bagian dari indikator kemampuan komunikasi matematis. 
Dari penjelasan di atas dapat disimpulkan dimana pembelajaran yang dilakukan di sekolah belum sepenuhnya dapat meningkatkan komunikasi matematis siswa. Menurut penelitian yang dilakukan oleh (Deswita \& Kusumah, 2018) dan (Hariyanto, 2017) yaitu kenyataan di lapangan menunjukkan bahwa kemampuan komunikasi matematis siswa masih renda, begitupun dengan penelitian yang dilakukan oleh. Rendahnya tingkat kemampuan komunikasi matematis siswa di sekolah perlu mendapatkan perhatian yang lebih dari berbagai pihak.

Diskusi kelompok merupakan cara penyajian pelajaran dimana siswa diharapkan dapat meningkatkan kemampuan komunikasi matematisnya, dimana dalam pembelajaran secara berkelompok siswa akan lebih aktif dalam mengkomunikasikan ide-ide siswa baik lisan maupun tulisan. Model pembelajaran yang memenuhi kriteria yang telah disebutkan adalah model pembelajaran kooperatif. Menurut (Isjoni, 2016) Pembelajaran kooperatif merupakan strategi belajar dengan sejumlah siswa sebagai anggota kelompok kecil yang tingkat kemampuannya berbeda.

Model pembelajaran kooperatif yang dapat mengembangkan kemampuan komunikasi matematis adalah model pembelajaran yang pada tahapan-tahapannya dapat menuntun siswa untuk dapat membuat dugaan sementara, merumuskan definisi serta melibatkan siswa dalam kegiatan diskusi. Menurut (Agata, 2016) model pembelajaran koooperatif tipe connecting, organizing, reflecting, dan extending (CORE) adalah model pembelajaran kooperatif yang langkah-langkahnya memenuhi kriteria yang telah disebutkan. CORE merupakan salah satu tipe dari model pembelajaran kooperatif, dimana dalam pembelajaran kooperatif siswa dituntut untuk aktif dalam pembelajaran secara berkelompok. CORE merupakan model pembelajaran yang menekankan pada 4 aspek penting dalam pembelajaran yaitu model pembelajaran Connecting, Organizing, Reflecting, Extending (CORE).

Menurut Calfee dalam (Krisno, 2016), model pembelajaran CORE adalah model pembelajaran yang mengharapkan siswa untuk dapat mengkonstruksi pengetahuannya sendiri dengan cara menghubungkan (Connecting) dan mengorganisasikan (Organizing) pengetahuan baru dengan pengetahuan lama kemudian memikirkan kembali konsep yang sedang dipelajari (Reflecting) serta diharapkan siswa dapat memperluas pengetahuan mereka selama proses belajar mengajar berlangsung (Extending). Adapun langkah-langkah dari model pembelajaran CORE menurut (Aris, 2017) yaitu (1) Guru mengawali pembelajaran dengan hal-hal yang menarik, (2) Guru menyampaikan materi prasyarat atau materi yang pernah dipelajari dan dihubungkan dengan materi yan akan dipelajari, (3) Siswa mengorganisasikan ide-ide untuk memahami konsep baru dengan guru, (4) Siswa dibagi menjadi beberapa kelompok yang terdiri dari 4-5 orang dalam setiap kelompok, (5) Siswa memikirkan kembali, mendalami dan menggali informasi yang sudah didapatkan saat belajar berkelompok, dan (6) Siswa mengembangkan, memperluas, menggunakan pengetahuan dalam tugas individu yang diberikan. 
Berdasarkan latar belakang maka, tujuan penelitian ini adalah untuk mengetahui pengaruh model pembelajaran CORE terhadap kemampuan komunikasi matematis siswa pada siswa kelas VIII SMPN 2 Kediri tahun ajaran 2019/2020.

\section{METODE PENELITIAN}

Jenis penelitian yang digunakan adalah eksperimen semu atau quasi experimental. Desain penelitian yang digunakan adalah Posttest Only Control Group Design. Penelitian ini dilaksanakan di SMP Negeri 2 Kediri. Populasi pada penelitian ini yaitu seluruh siswa kelas VIII SMP Negeri 2 Kediri tahun ajaran 2019/2020 sebanyak 79 siswa. Populasi tersebar ke dalam 3 kelas A, B, C yang homogen, sehingga teknik pengambilan sampel dipilih cluster random sampling. Sampel penelitian sebesar 54 siswa yang tersebar pada kelas B sebanyak 28 siswa dan kelas C sebanyak 26 siswa.

Pada penelitian ini, kelas VIII-B sebagai kelas eksperimen yang menggunakan model pembelajaran kooperatif tipe CORE (Connecting-Organizing-Reflecting-Extending), sedangkan kelas VIII-C sebagai kelas kontrol yang menggunakan model pembelajaran langsung. Penelitian ini dilakukan sebanyak empat kali pertemuan pada masingmasing kelas eksperimen dan kontrol, dimana empat kali pertemuan tersebut terdiri dari tiga kali pertemuan untuk melakukan proses pembelajaran dan satu kali digunakan untuk melakukan post test. Variabel bebas dalam penelitian ini adalah model pembelajaran kooperatif tipe CORE, dan variabel terikat dalam penelitian adalah kemampuan komunikasi matematis siswa. Teknik pengumpulan data yang digunakan yaitu observasi dan tes. Instrumen yang digunakan dalam penelitian adalah lembar observasi yang terdiri dari lembar observasi aktivitas mengajar guru dan lembar observasi aktivitas belajar siswa, serta soal tes (post test). Uji validitas instrumen menggunakan validitas isi dilakukan oleh seorang dosen pendidikan matematika Universitas Mataram dan validitas empiris dilakukan dengan mengujicobakan instrumen terlebih dahulu kepada 27 responden. Responden yang dimaksud adalah siswa SMPN 16 Mataram yang sudah lebih ahulu mempelajari materi kubus dan balok.

Teknik analisis data yang digunakan dalam penelitian ini adalah teknik analisis statistik deskriptif dan analisis statistik infrensial. Analisis statistik deskriptif digunakan untuk menganalisis data dengan cara mendeskripsikan atau menggambarkan data yang telah terkumpul sebagaimana adanya tanpa bermaksud membuat kesimpulan yang berlaku untuk umum atau generalisasi (Sugiyono, 2017). Sedangkan analisis statistik infrensial digunakan untuk menguji hipotesis penelitian. Namun sebelumnya dilakukan terlebih dahulu uji prasyarat analisis. Pengujian persyaratan analisis data yang digunakan terdiri dari: (1) Uji normalitas menggunakan uji chi square diperoleh nilai $\chi^{2}{ }_{\text {hitung }}$ kelas eksperimen sebesar -21,9093 dan kelas kontrol sebesar -50,3626 kedua nilai tersebut kurang dari $\chi^{2}$ tabel yaitu 11,070, maka data populasi berdistribusi normal. (2) Uji homogenitas menggunakan uji fisher diperoleh nilai $F_{\text {hitung }}$ sebesar 1,07 nilai tersebut kurang dari $F_{\text {tabel }}$ yaitu 1,939, maka data dari nilai posttest kelas eksperimen dan kelas kontrol memiliki variansi yang sama 
atau homogen. Sedangkan pengujian hipotesis yang digunakan yaitu uji-t dua arah dengan taraf signifikan 5\%. Karena jumlah anggota sampel kedua kelas tidak sama dan varisans homogen maka rumus uji-t yang digunakan adalah Rumus Pooled Varians. Rumus Pooled Varians menurut (Sugiyono, 2010) yaitu:

$$
t=\frac{\bar{x}_{1}-\bar{x}_{2}}{\sqrt{\left(\frac{\left(n_{1}-1\right) S_{1}^{2}+\left(n_{2}-1\right) S_{2}^{2}}{n_{1}+n_{2}-2}\right)\left(\frac{1}{n_{1}}+\frac{1}{n_{2}}\right)}}
$$

Setelah didapatkan $\mathrm{t}$ hitung, kemudian $\mathrm{t}$ hitung dikonsultasikan dengan $\mathrm{t}$ tabel pada taraf signifikasi 5\%. Jika $t_{\text {hitung }}>t_{\text {tabel }}$ maka $H_{0}$ ditolak dan $H_{1}$ diterima. Sedangkan jika $t_{\text {hitung }}<t_{\text {tabel }}$ maka $H_{0}$ diterima dan $H_{1}$ ditolak.

Hipotesis yang diuji adalah:

$H_{0} \quad$ : Tidak terdapat perbedaaan kemampuan komunikasi matematis siswa yang menggunakan model pembelajaran langsung kelas VIII SMPN 2 Kediri.

$H_{1} \quad$ : Terdapat perbedaaan kemampuan komunikasi matematis siswa yang menggunakan model pembelajaran kooperatif tipe CORE kelas VIII SMPN 2 Kediri.

\section{HASIL DAN PEMBAHASAN}

\subsection{Hasil Penelitian}

\subsubsection{Hasil Lembar Observasi}

Melihat keterlaksanaan pembelajaran di kelas eksperimen dan kontrol, digunakan lembar observasi aktivitas mengajar guru dan aktivitas belajar siswa yang telah valid dilakukan sebanyak 3 kali pertemuan, dengan hasil sebagai berikut.

Tabel 1. Hasil Lembar Observasi Aktivitas Mengajar Guru dan Aktivitas Belajar Siswa

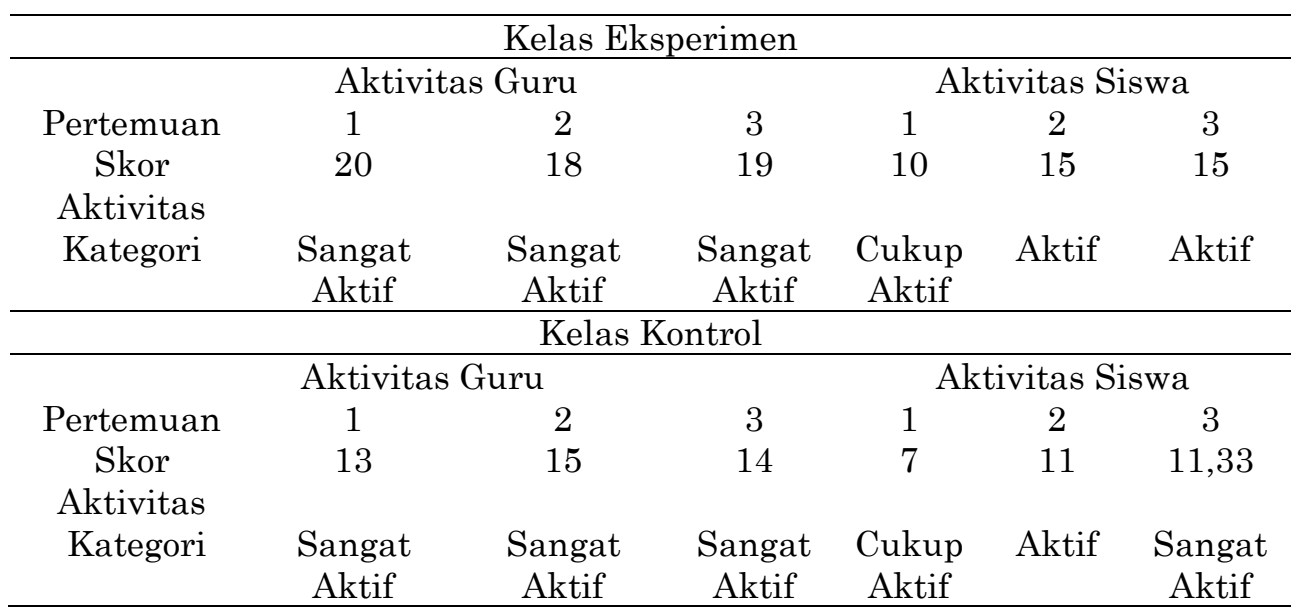


Berdasarkan Tabel 1, diketahui bahwa aktivitas mengajar guru di kelas eksperimen dan kontrol sama-sama berkategori sangat aktif di ketiga pertemuan. Begitupun dengan aktivitas belajar siswa di kelas eksperimen dan kontrol, aktivitas belajar di pertemuan pertama mencapai kategori cukup aktif, dan untuk kelas eksperimen pada pertemuan ke dua dan ketiga mencapai kategori aktif, sedangkan kelas kontrol pada pertemuan kedua mencapai kategori aktif dan pertemuan ketiga mencapai kategori sangat aktif.

\subsubsection{Hasil Tes Kemampuan Komunikasi Matematis}

Hasil perhitungan nilai posttest kemampuan komunikasi matematis siswa baik kelas eksperimen maupun kelas kontrol dapat dilihat pada Tabel 2.

Tabel 2. Hasil Posttest Kemampuan Komunikasi Matematis

\begin{tabular}{ccc}
\hline Kelompok Data & \multicolumn{2}{c}{ Data Hasil Posttest } \\
\cline { 2 - 3 } & VIII B (Eksperimen) & VIII C (Kontrol) \\
\hline Nilai Terendah & 45 & 43 \\
Nilai Tertinggi & 98 & 90 \\
Nilai Rata-Rata & 77.85714 & 65.15385 \\
Standar Deviasi & 11.59411 & 12.00897 \\
Varians & 134.42 & 144.21 \\
Jumlah Siswa & 28 & 26 \\
\hline
\end{tabular}

\subsubsection{Analisis Statistik Inferensial}

Pengujian hipotesis dilakukan dengan menggunakan Uji-t jenis Polled varians, karena jumlah siswa pada kedua kelas tidak sama dan juga data homogen. Setelah dilakukan perhitungan uji t diperoleh data seperti yang disajikan pada tabel berikut:

Tabel 3. Hasil Uji-t Data Posttest

\begin{tabular}{cccccccc}
\hline Kelas & $\begin{array}{c}\text { Jumlah } \\
\text { Siswa }\end{array}$ & $\begin{array}{c}\text { Rata- } \\
\text { rata }\end{array}$ & $\begin{array}{c}\text { Varian } \\
\mathrm{s}\end{array}$ & $t_{\text {hitung }}$ & Sig. & $t_{\text {tabel }}$ & Kesimpulan \\
\hline VIII-B & 28 & 77.86 & 134.42 & 3.95654 & 0,05 & 1.67469 & $H_{0}$ ditolak \\
VIII-C & 26 & 65.15 & 144.21 & & & &
\end{tabular}

Berdasarkan Tabel 3, terlihat hasil uji hipotesis diperoleh nilai $t_{\text {hitung }}>t_{\text {tab el }}$, maka $H_{0}$ ditolak. Hal ini berarti bahwa terdapat perbedaan rata-rata hasil kemampuan komunikasi matematis siswa kelas eksperimen dan kelas kontrol, yaitu kelas eksperimen 77,86 dan kelas kontrol 65,15. Sehingga terdapat perbedaan rata-rata hasil kemampuan komunikasi matematis sisa antara kelas eksperimen dan kelas kontrol pada siswa kelas VIII SMP Negeri 2 Kediri. 
Berdasarkan hasil analisis data nilai posttest diperoleh bahwa kemampuan komunikasi matematis siswa kelas eksperimen dan kontrol berdistribusi normal. Pengujian homogenitas sesudah pemberian perlakuan menunjukkan bahwa seluruh kelompok data memiliki varian yang homogen. Dari hasil perhitungan uji hipotesis dengan menggunakan uji t-test sampel independen pada taraf signifikan $5 \%$, diperoleh nilai $t_{\text {hitung }}$ sebesar 3,95654 dan nilai $t_{\text {tabel }}$ sebesar 1,67469. Berdasarkan hasil analisis data, nilai $t_{\text {hitung }}>t_{\text {tabel }}$ yaitu $(3,95654>$ 1,67469). Sehingga, dapat disimpulkan bahwa terdapat perbedaan yang signifikan antara hasil kemampuan komunikasi matematis siswa kelas VIII SMP Negeri 2 Kediri yang diajarkan dengan model pembelajaran kooperatif tipe $C O R E$ dan model pembelajaran langsung.

\subsection{Pembahasan}

Hasil penelitian ini mengungkap kelebihan dan kekurangan dari model kooperatif tipe CORE yang telah diterapkan. Berdasarkan hasil pembelajaran di kelas eksperimen, dapat dikatakan bahwa kelebihan dan keurangan model ini sesuai dengan pernyataan (Krisno, 2016). Kelebihannya diantaranya yaitu bahwa model pembelajaran CORE mampu membantu siswa dalam menguasai konsep baik teori maupun penerapannya dalam kehidupan sehari-hari, hal ini karena model pembelajaran CORE dapat menjadikan siswa lebih aktif dalam belajar, terbukti pada saat proses pembelajaran rasa ingin tahu siswa lebih tinggi karena untuk dapat berperan aktif, maka siswa harus dapat mengingat informasi dan menggunakan pengetahuannya untuk menghubungkan topik yang didiskusikan. Selain itu, model pembelajaran CORE juga dapat melatih daya ingat siswa tentang suatu konsep/unformasi, dimana siswa mengatur dan mengorganisasikan informasi dari berbagai sumber menjadi suatu pengetahuan baru baik dengan cara meringkas hasil-hasil penting dalam diskusi atau menuliskan langkah-langkah yang menghubungkan antara pengetahuan lama dengan pengetahuan baru yang mereka diskusikan. Siswa juga dilatih untuk berpikir reflektif baik sebelum maupun sesudah diskusi agar siswa mampu menyelesaikan masalah berbeda namun memiliki dasar konsep yang sama menggunakan pengetahuan lama dan pengetahuan baru yang dimiliki, serata memberikan siswa pembelajaran yang bermakna, diskusi membantu siswa memperluas pengetahuannya, diskusi dilakukan untuk memperoleh berbagai macam informasi dari teman-teman dan gurunya sesuai topik serta mencoba untuk menjelaskan kembali kepada temanteman dan guru. Sedangkan, kekurangan model kooperatif tipe CORE diantaranya yaitu pengolaan waktu, karena model pembelajaran CORE ini membutuhkan persiapan yang optimal dari guru serta memerlukan banyak waktu, dan juga tidak semua materi pelajaran dapat menggunakan model CORE. 
Dengan kemampuan komunikasi matematis yang dimiliki siswa dapat memecahkan masalah matematika dengan menggunakan bahasa sehari-hari sebagai bentuk komunikasi dengan teman sekelas, terlebih lagi dengan menggunakan simbol dan kosakata matematika secara benar dan lancer merupakan bagian penting dalam pembelajaran matematika. Namun sebagian besar siswa pada umumnya enggan untuk mengadakan pembicaraan mengenai matematika kecuali untuk tujuan menyelesaik tugas-tugas yang diberikan gurunya. Dalam perspektif ini pun, banyak siswa yang hanya mengikuti jalan pikiran atau bahkan meniru penyelesaian soal dari teman sekelasnya yang dianggap mampu atau pintar. Maka sebagai guru tugas yang utama untuk meningkatkan kemampuan komunikasi matematis siswa yaitu dengan mengetahui dan menganalisa siswa kurang kreatif dan kurang mampu dalam menguasai pelajaran sehingga guru dapat mengarahkan dan membimbing siswa kea rah yang lebih baik.

Perbedaan kemampuan komunikasi matematis siswa disebabkan karena adanya perlakuan pada kedua kelas yaitu pada kelas eksperimen diterapkan model pembelajaran kooperatif tipe CORE dan di kelas kontrol diterapkan model pembelajaran langsung. Dalam penerapan model pembelajaran kooperatif tipe CORE di kelas, siswa melakukan pembelajaran dalam bentuk kelompok dan berdiskusi sehingga terjadi proses pembelajaran multi arah yaitu dari guru ke siswa, dari siswa ke guru, dan dari individu siswa ke kelompok. Selama proses pembelajaran siswa menjadi lebih aktif, semangat, dan lebih cepat mengerti materi yang sedang dipelajari. Hal ini dapat dilihat ketika siswa membaca, menulis, berbicara, bertanya, dan mendengarkan pada saat diskusi kelompok berlangsung. Selain melaksanakan diskusi, dilakukan juga proses tanya jawab antar siswa dengan guru. Pertanyaan-pertanyaan yang diberikan berkaitan dengan materi yang sedang dipelajari. Pada proses tanya jawab, terlihat siswa mampu menyampaikan kembali apa yang telah dibahas ketika diskusi kelompok. Hal ini terlihat ketika siswa mendapat pertanyaan dari guru, siswa cenderung menjawab secara langsung sesuai dengan pemikirannya sendiri bahkan ada siswa yang mengemukakan pendapatnya secara langsung tanpa diminta. Hampir dari semua siswa tidak ada yang tidak menjawab pertanyaan guru, setiap siswa yang mengangkat tangan menjawab pertanyaan guru meskipun jawabannya kurang tepat. Sejalan dengan penelitian (Siregar, 2018) yang menyatakan bahwa model pembelajaran CORE merupaka model pembelajaran yang menggunakan pendekatan konstruksivisme dengan kegiatan pembelajaran berpusat pada siswa dan guru bertindak sebagai fasilitator.

\section{SIMPULAN}

Berdasarkan data hasil penelitian dan pembahasan yang telah dibahas sebelumnya, dapat disimpulkan bahwa nilai rata-rata kelas eksperimen yang menggunakan model pembelajaran kooperatif tipe CORE lebih besar dari pada nilai rata-rata kelas kontrol yang menggunakan model pembelajaran langsung. Hal ini menunjukkan bahwa pembelajaran dengan model pembelajaran kooperatif tipe $C O R E$ berpengaruh terhadap 
kemampuan komunikasi matematis siswa kelas VIII SMP Negeri 2 Kediri tahun ajaran $2019 / 2020$.

\section{UCAPAN TERIMA KASIH}

Ucapan terima kasih disampaikan kepada dosen pembimbing, Ibu Syahrul Azmi, S.Pd., M.Pd., dan Bapak Muhammad Turmuzi, S.Pd., M.Pd., yang telah meberikan bantuan berupa masukan dan saran sehingga memperlancar proses penyelesaian kegiatan penelitian ini. Tak lupa pula disampaikan terima kasih kepada keluarga dan temanteman yang selalu memberikan semangat dan doa sehingga laporan penelitian ini dapat diselesaikan.

\section{REFERENSI}

Agata, I. P. (2016). Pengaruh Pembelajaran Kooperatif Tipe CORE Terhadap Kemampuan Komunikasi Matematis. Universitas Lampung FKIP. www.iranesrd.com

Ansari, B. I. (2016). Komunikasi Matematik Strategi Berfikir dan Manajemen Belajar Konsep dan Aplikasi. PeNA. www.iranesrd.com

Aris, S. (2017). 68 Model Pembelajaran Inovatif dalam Kurikulum 2013. AR-RUZZ MEDIA.

Asnawati, S. (2017). Peningkatan Kemampuan Komunikasi Matematis Siswa Smp Dengan Pembelajaran Kooperatif Tipe Teams-Gamestournaments. Euclid, 3(2), 561-567. https://doi.org/10.33603/e.v3i2.332

Deswita, R., \& Kusumah, Y. S. (2018). Peningkatan Kemampuan Komunikasi Matematis Siswa Melalui Model Pembelajaran CORE dengan Pendekatan Scientific. Edumatika: Jurnal Riset Pendidikan Matematika, 1(1), 35. https://doi.org/10.32939/ejrpm.v1i1.220

Hariyanto. (2017). Penerapan Model CORE dalam Pembelajaran Matematika untuk Meningkatkan Kemampuan Komunikasi Matematik Siswa. Jurnal Gammath, 2(1), 11-19. http://jurnal.unmuhjember.ac.id/index.php/JPM/article/view/575

Hodiyanto. (2018). Komunikasi matematis dalam pembelajaran matematika. Logaritma: Jurnal Ilmu-Ilmu Pendidikan Dan Sains, 6(02), 74. https://doi.org/10.24952/logaritma.v6i02.1275

Isjoni. (2016). Cooperativ Learning. Alfabeta.

Krisno, A. B. (2016). SINTAKS 45 Model Pembelajaran dalam Student Centered Learning (SCL). Universitas Muhammadiyah.

Siregar, R. M. R. (2018). Pengaruh Model Pembelajaran Connecting, Organizing, Reflexting, Extending Terhadap Kemampuan Komunikasi Matematis Mahasiswa. Jurnal Mathematic Paedagogic, 2(2), 188. https://doi.org/10.36294/jmp.v2i2.218

Sugiyono. (2010). Metode Penelitian Pendidikan Pendekatan Kuantitatif, Kualitatif dan R\&D. Alfabeta.

Sugiyono. (2017). Metode Penelitian Pendidikan Pendekatan Kuantitatif, Kualitatif dan R\&D. Alfabeta. 